\title{
The Typologies of Parental Involvement in Katsina State Primary Schools
}

\author{
Ahmed Tijjani Ibrahim \\ School of Educational Studies, Unversiti Sains Malaysia \\ Mobile Phone: +60143306304. E-mail: tijjani.ahamad@yahoo.com \\ Hazri Bin Jamil \\ School of Educational Studies, Unversiti Sains Malaysia \\ Mobile Phone: +60143306304. E-mail: hazri@usm.my \\ Annah Christina Abdullah \\ School of Educational Studies, Unversiti Sains Malaysia \\ Mobile Phone: +60164854125. E-mail: achristi@usm.my
}

Accepted: July 4, 2012 Published: July 09, 2012

Doi:10.5296/ijld.v2i4.2073 URL: http://dx.doi.org/10.5296/ijld.v2i4.2073

\begin{abstract}
The purpose of this case study is to investigate parental involvement in the schooling process of their children through the six typologies of Parental involvement within the two selected primary schools in Katsina state of Nigeria. The study used qualitative case study method, students, parents, and teachers, of the two selected primary schools in Katsina state were interviewed. In addition to the interviews, observations were conducted; school documents were used as instruments for data collection. The study shows that parent involved in the schooling process of their children through six typologies of parental involvement. The result also indicated that parents in SA use all thesix typologies to get involve while SB uses parenting \& decision making more than the rest. The finding also indicated that there is a low level of meaningful contact between school, parents and community members within School B. Apathy exists on the side of parents, low expectations on the side of School teachers, and there is no organisational structure to facilitate parental involvement in the school. The students whose parents were involved in their schooling process achieved more academic success at school than students whose parents were less involved. The study contributed to the body of knowledge by adding insightful information to the knowledge base surrounding the
\end{abstract}


Implementation of the Eptein's (1998) Typologies of parental involvement for facilitating academic success in Kasina State, Nigeria.

Keywords: schooling process, academic success, school, family and community partnership.

\section{Introduction}

Lawal (1985), Okebukola (2004), and Adeosun (2010) highlighted that parental involvement in the schooling process of their children is as far lower at the lower basic educational level as most primary school pupils were totally illiterate at the end of their primary education. These problems are usually spillovers from the earlier stages of educational system in Nigeria. Kazeem and Musa (2008) suggested the need for a study on the implementation of the six Typologies of parental involvement of a model of school and family involvement Epstein's (2006) in the Nigerian context. The present study therefore, intended to explore parental involvement through the six typologies of parental involvement. Katsina is choosen as the study area because it is considered as one of the areas that has an acute shortage of literature in the area of parental involvement (Adepuju, 2010, Kazeem \& Musa 2008, Adenike \& Osoji 2010).

The importance of parental involvement is strongly supported by research (Henderson \& Mapp 2002). Many studies indicated that good parent-teacher relationship lead to improved student academic success, self-esteem, school attendance and social behaviour, reduced drop-out rates, and provides more positive communication; and improved school programmes and school climate (Banks \& Banks, 1997; Chavkin, 1993; Epstein, 1995a; Hester, 1989; Jones \& Blendinger, 1994; Lemmer, 2000; Squelch \& Lemmer, 1994, p. 13; Van Wyk \& Lemmer, 2009). Furthermore, research shows that teachers who frequently involve parent in their children's schooling process facilitate children academic success, and these parent are equally helpful with their children at home when shown how to be so (Epstein \& Sanders 2000). The aim of this article is to examine parent-teacher relations using Epstein's six typologies of parental involvement from the selected Primary Schools in Katsina; the following research question was investigated:

\section{Research Question}

How parents get involved in the schooling process of their children through the six typologies of parental involvement?

\section{Parental Involvement in Children's Schooling}

The No Child Left Behind Act (2001) defined parental involvement as the participation of parents in regular, two way and meaningful communication involving student academic learning and other school activities. The North West Regional, Educational Laboratory 
(NREL, 1999) defined parental involvement as the active, ongoing participation of a child's parent or guardian in his or her education. Epstein (1995), refers to the concept of parental involvement as families and communities who take active part in creating a caring educational environment (Eisenhart \& Towne, 2003). Caring involvement here is referred to as parental actual engagement in the schooling activities of their children, through identifying, and integrating resources and services that will encourage their children and help them to succeed academically (Epstein, 1995).

These conceptions portray the fact that educating children in a time and society which has the characteristics of ethnic diversity, economic instability, and social maladjustment, requires contributions and commitments from everyone in the community. Hence, establishing an effective partnership among families, schools, and communities is regarded as crucial for the optimal academic success throughout the child's academic career (Bryan \& Holcomb-McCoy, 2007). The main reason for involving parents in their children's education is to help the youngsters to succeed in school and in later life. When parents, teachers, students, and others view one another as partners in education, a caring community forms around students and it begins to work (Epstein, 1995).

The actual circumstances of each of the two selected schools determine how parental involvement should be planned at that school (Botha, 2000). In spite of this, Lemmer (2007) explained that effective school, family and community partnership models demonstrate certain common themes:

1. Effective school, family, and community partnership models are school based and school driven 2. They should conceptualize school, family, and community in a broad and flexible manner. 3. There should be effective partnership models that allow for a continuum of involvement: from complex school-based activities (such as assisting in the school) to simpler home-based activities (such as monitoring children's homework activities or assisting in the school library). 4. The partnership models should form part of a school improvement plans that are linked to specific outcomes of the students in the school.

In addition to these common themes, Williams and Chavkin (1989, pp. 18-20) listed seven elements that should be an integral part of any parental involvement programs:

1. There should be written policies that specify areas for parent involvement. 2. Provision of administrative support (resources such as a meeting venue and duplicating facilities, funds and personnel). 3. There should be continuous training of teachers and of parents in elements of parent involvement. 4. Provision of partnership approaches which help parents and teachers to develop attitudes of ownership towards the school and take pride in it. 5. Provision of two-way communication, i.e. regular communication between parents and school, e.g. newsletters, personal visits, telephone calls, and emails should be provided by the school to the parents. 6 . Parents should liaise with the school regarding parental involvement programs by helping 
participants to benefit from each others' experiences. 7. There should be continuous evaluation of the school's parental involvement programme.

Van der Linde (1997, p. 40) adapted Bastiani's model (1996) where he specified the following areas for developing school, family, and community partinership:

1. There should be communication of information; making proper arrangements to discuss problems of individual children by involving parents in their children's schooling process so as to help in running the school. 2. Interest should be developed in understanding the support for the school work. 3. There should be proper use of parental skills, interests and experiences. 4. There should be provision of opportunities for parents' education and development. 5. The views of parents should be considered in decision-making policy of the school; active involvement with, and support for, family, school, and community involvement.

\section{Theoretical Context}

In selecting the theoretical model that fulfils the above stated criteria and is used all over the world in the area of parental involvement, the study chooses the theoretical model that was developed by Joyce Epstein. In the 1980s, Epstein developed a theoretical perspective called 'overlapping spheres of influence' that posited that the most effective families have overlapping shared goals and missions concerning children (Epstein, 1995b, p. 214). The model recognized that that the three major contexts in which children learn and grow - the family, school and community - could be drawn together or pushed apart. Epstein (2001, pp. 408-410) described six types of family-school-community involvement falling within the areas of overlapping spheres.

Type 1 Epstein terms Parenting. The school helps families to establish home environment to support children in their schooling process through organizing workshops and meetings.

Type 2 is communicating. This is refers to the process of designing an effective form of school-home and home -school communication about school's programs so that parents will always have an up-to-date information about the school progress. Possible means of communicating with parents include letters, written reports/profiles, parent evenings and home visitation.

Type 3 Volunteering, refers to recruiting and organizing parental help and support at school so as to practically contribute towards improving the academic standard of their children.

Type 4 learning at home, this entails the provision of information and ideas to families about how to help their children with homework and other curriculum-related activities, decisions and planning that contributes to their success in school.

Type 5 Decision-making is the process of involving parents in the school decision making process. They should have a say in the school related affairs which directly or indirectly affect the schooling process of their children 
Type 6 Collaborating with the community, means identifying and integrating resources and co-services from the community to strengthen school programs, family practices, and student learning and development.

Epstein (1995a, p. 707) asserted that the six types of involvement could guide the development of a balanced, comprehensive program of partnership, with potentially important results for students, parents and teachers.

\section{Conceptual Framework of the study}

The conceptual framework guiding this study is Joyce Epstein's overlapping spheres of influence and her six typologies of parental involvement (Epstein, 2001). In order to have a clear understanding of Epstein's theory, it may be useful to first of all understand a previous theory that influenced her development of overlapping spheres of influence. Prior to this theory of overlapping spheres of influence, there was a theoretical model of family and school involvement that highlighted "separate, shared, and sequential responsibilities" of schools, families and communities. The work of Uri Bronfenbrenner influenced Epstein's development of overlapping spheres of influence.

The three spheres in Epstein's model refer to the family, school, and the community locating the child at the center. Whether these three spheres of influence interact and influence each other to benefit the student in his schooling process depends largely on the factors of experiences at home, experiences at school, and experiences in the community which come through involvement activities (parenting, communicating, volunteering, learning at home, decision making, and collaborating with community). When children are exposed to these activities by the school, family and community whose only goal is to interact and collaborate with each other to influence students' academic success, the students become the winners in their schooling process (Epstein, 2001).

Figure 1 indicates the overlapping spheres of influence in Epstein's model which is referred to as parental involvement. When the three major players that is school, family, and community establish a partnership, the partnership activities will support, motivate and guide the students to achieve success in their schooling process. Epstein views the school and home as mingling and overlapping that bring about cohesiveness to the well-being of students in their schooling process. In Figure 1, the researcher has drafted a diagram of what he believes is the best way to describe the flow of partnership through schooling process to academic success. The researcher outlined and define the terms as he walk through the concept map that follows.

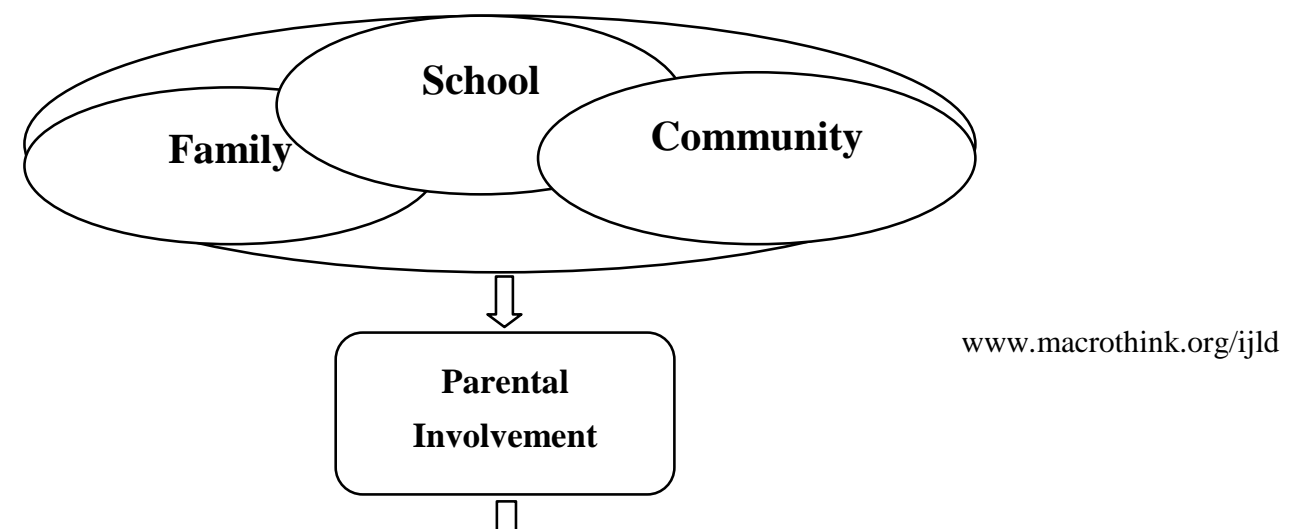


Figure 1: Conceptual framework of the six typologies of school, family, and community partnership, Overlapping Spheres of Influence( Epstein,1998).

The first box in the center includes a diagram of the three different concepts school, family, and community. The theory of overlapping spheres of influence stated that when the internal structure of the theory (school, family, and community) overlap with external structure (the pattens of interaction between the three spheres) is called parental involvement. The next category outlines the six typologies which emanate from the interaction of the three spheres of influence as activities that will facilitate the partnership between family, school, and community. In other words they are the process through which parents involve themselves in the schooling process of their children. The third cycle indicates how the typologies affect the schooling process of the students.

The final cycle indicates the way students' academic success is influenced by the students schooling process. As indicated in the figure, when the three spheres of influence overlapp they are defined as parental involvement. The six typologies of school, family, and community partnerships are called activities of involvement. By implementing the six activities in the educational process of student it will have an effect on the schooling process of the child as stated in the conceptual framework and then lastly influence the academic success of the child.

\section{Research Methodology}


In this study the researcher opted to use a qualitative approach because the researcher wished to obtain a more detailed understanding on the implementation of the six typologies of parental in the study area. According to Neuman (2000) qualitative report is preferred because of its descriptive nature, colorful details whereby its characters are unique rather than formal and neutral to the statistics. Mertens (1998) adds that qualitative research studies the phenomenon in its natural state and tries to make sense out of it. Strauss and Corbin (1990) describe qualitative research as any type of research that produces findings or results by not using statistical methods.

\section{Research instruments}

In quantitative study, a variety of instruments can be used for gathering data, such as surveys, tests, and questionnaires (Hatch, 2002). Qualitative study, however, focuses on meaning in context, which necessitates an instrument for collecting data that is sensitive to its underlying meaning (Merriam, 1998, p.1). It follows, therefore that it is the researcher in qualitative study that will choose the instruments by which data are gathered. This field of thought is built upon from human capacity to think, reason, feel, participate in society-the identical qualities needed by qualitative researchers to "make sense of the actions, intentions, and understandings of those being studied" (Bogdan \& Biklen, 1992; Hammersley \& Atkinson, 1983; Lincoln \& Guba, 1985; Spradley, 1979). The present study use interviews, observation and school records as method for data collection. These data collection methods in this study are important because they enhance the trustworthiness of the data. This is supported by McMillan and Schumacher (2001) when stating that data collection method may yield and increase the credibility of findings.

\section{Subject Informant of the study}

The respondent/ participants used in this study were 32 participants. The actual participants were 8 students as indicated by Morse, (1994) the parents and teachers of these 8 students made part of the participants so that the data collected from them was used in validating the findings identified from the initial 8 participants. These participants came out from two primary schools. The schools were sampled from Katsina metropolis based on the performance of their students in the last concluded exams. The school that took first position and the one taking last position were selected for the purpose of the study.

Table; 1: Numbers of participats for the study.

$\begin{array}{llll}\text { Participants } & \text { School A } & \text { School B }\end{array}$

$\begin{array}{llll}\text { Students } & 4 & 4 & 8 \\ \text { Parents } & 8 & 8 & \end{array}$


Teacher

Head teacher

Total

\section{3}

1

\section{3}

1

2012, Vol. 2, No. 4

6

2

16

16

32

The names of the participants were selected through purposive sampling in order to select a representative sample from the population. Purposive sampling was implemented in order to gain insightful, thick, rich information (Patton, 1990). Parents were chosen through their children.

\section{Ethical Considerations}

Ethical considerations are extremely important aspect of qualitative research, the present study consider it necessary to engage in ethical practices. Based on this the researcher adhered to the following ethical measures:

Permission to conduct the research was obtained from the Universal Basic Education Board Katsina in Katsina state of Nigeria. The Universal Basic Education Board Katsina Permitted the researcher to conduct his study in the two selected Primary schools. The schools are: Mohd Dodo Ibrahim Science Model Primary school and Sararin Kuka Primary school.

Consent forms, together with an information letter which included detailed information on the purpose of the research and how data will be collected was given to the participants involved in the study. The study employed all the reasonable measures to ensure that the participants were protected from harm as a consequence of this research. And the study protected the anonymity of the schools and that of all the participants in the study.

In the process of interview audio recordings were made with the permission of the participants in order to capture their responses. The participants were informed that participation was voluntary and that they can withdraw from the study at any point, without any penalty.

The three set of participants shared their ideas with regard to the parental involvement through the six Parental involvement activities.

\section{School settings}

The two schools involved in the study are primary schools in Katsina metropolis. The first school (SA) is Mohd Dodo Ibrahim Science Model Primary School; it is one of the first graded schools in Katsina with an enrollment of 1074 both males and female Pupils in 2010- 2011 session with breakdown of 528 males and 546 females. The school has 35 teaching staffs, 05 non teaching staffs, and 11 classrooms. The school was established in the year 1988 with one session and in the early 2002 it is divided into morning and afternoon sessions, and also in 2006 it is remerged into one school. 
The second school (SB) is Sararin Kuka Primary School; the school is one of the second graded schools in the state. The school was established in 1961 with the enrollment started of a single classroom containing forty five pupils who were the pioneers of the school. The school is located in the western direction of Katsina town it has an enrollment of 1425 pupils containing both males and females with 26 teaching and non teaching staffs. The school has 10 classes and four staffrooms.

\section{Results}

In this section, the researcher discusses the ways parents involved in the schooling process through the six typologies of parental involvement. The section focuses on the interviewees' perceptions on the implementation of the six typologies, followed by analysis of the interviewees' responses, researcher's observation and schools document on the implementation of the typologies in the schooling process of the children. The intention in this section is to develop an understanding of how the six typologies are implemented in the selected sites of the study.

The following provides interviewees responses, researcher's observations and schools policy document on the implementation of the six typologies of parental involvement within the selected schools of the study.

\section{Parenting}

Parenting is one of the involvement activities; it is the process of helping all families to establish home environments and to support their children in their schooling process.

\section{Ways of Parenting and Parental Services}

Parents establish conducive home environments and support their children in their daily affairs. They provide health, safety and shoulder all the responsibilities of their children by providing daily bread and creating encouraging environment for learning and behavior development.

The participants in this research added much insightful information about their experiences as a parents or guardians. When asked by the researcher to explain their parental responsibilities one interviewee responded that parents are the most influential advocates to their child they guide him, take care of his physiological needs, and help in developing his behavior. This is done through getting involved into his education. Interviewee, (03 SA).

On the relationship between parenting and education, interviewee 03(SA) stated: "Well, I have the believe that education and our children are the keys to our future. We insist that our children should observe their homework first, as soon as they get home every night before going to bed. We make them do it neat and then we try to check over their work to make sure it is done right." The researcher asked another parent interviewee on what he thinks is the major responsibilities of parents to their children. The interviewee $(05 \mathrm{SB})$ responded that parents should take care of 
their child's needs in addition to his education, because they are the most significant pillars in the life of the children.

On the side of the children they responded that their physiological needs are being provided by their parents in addition to their educational facilities. Interviewee 05, 02 and 04 (SA). Also interviewees 02, 03, and 04 (SB).

Among the responsibilities of parents is taking care of their children education as indicated by the responses above. Some parents get themselves involve in all the schooling process of their children through administering reward and punishment, collaborating with schools, involving in the school activities and monitoring the progress of their children. The following responses from the interviewees on whether or not they reward or punish their children for good or bad performance in the school, and their ideas about involvement at school provide a clear picture on how the selected schools implement the concept of parenting. The responses from the participants read as follows:

"My children are expected to do their best, no matter what. They do not get a reward for doing good work, except for maybe the end of the 6 weeks, sometimes. I expect them to do well without money or anything behind it. We didn't get money for good performance when I was growing up, we were just expected to do well and if we didn't, well then we knew what was coming to us. I think too many parents give their children too much stuff for doing well and then the children expect a prize every time they turn around."

Interviewee 08

(SA

Parent).

"An involved parent makes contact with the teacher to make sure they are on the same page with the child's learning process. They also bring up any issues or concerns they might have. An involved parent also takes part in helping with parties, fundraising and any school activities. Education is a very important tool. We think it is important to make good results and go to school and have good attendance. Also, we try to make sure children go to school on time. After picked them up from school or the Boys and Girls club, they start their homework while dinner is cooking. If they done before dinner, one of us checks it and they are allowed to play. If their homework is not done before dinner, we make them finish after dinner. If there is a test or something during the week, we go over the study guide several times before they are allowed to play. If no study guide is provided at school, we make them one and then we go over it a bunch of times each night. If they bring home bad results, their punishment is that they should not watch TV or play at all, but if they bring home good results they are rewarded for that."

Interviewee 07

(SA

Parent). In general, the above responses to the question on parental responsibilities to their children from (SA) noted a uniformity of parents' perception of their involvement in the children schooling process as indicated in the quotations above. Because many of them believe 
that the second parental responsibility to their children after physiological needs is education. The majority of the parents reported their involvement experiences like through administering rewards and punishment, paying much attention to their home work, other school related activities at home, talking to the teachers and attending PTA meetings.

On the side of (SB) an interviewee 03 (SB) was asked by the researcher to described parents involvement in the schooling process of their children through parenting. The interviewee responded that for parents to be involve they must first of all provide all the physiological needs of their child, and then they should be familiar and comfortable with their child's teachers and head teachers and know what is going on at school, like games and just all kinds of activities so that good education is provided to improves the quality of your life.

One more parent stated, "'involved parents come in and help out by providing their children's need at home, and go to meetings and other things at school we believe our children should get a good education. We try to encourage them at home to do their best in school. If our children get bad results, then they are not supposed to ply and watch TV until their results improve. Sometimes, if the children do well in school or get extra good results, then we take them out to eat or whatever they want to do. My wife helps out so much with the children. I work a lot so she has to help them with their homework the best she can. She tries, but sometimes the stuff they bring home to do is even tricky for me and her. "Interviewee 05(SB).

Another parents reported actual physical involvement only in reference to staying active with everything your child does in school. The interviewee stated that: "I help my daughter with her homework when she is having trouble with a certain area in a subject. She does her work, when she is finished, then I check over it and the ones she has done wrong, we go over together so she can understand the problem. When she is having trouble in a subject, I go online and find worksheet or activities and have her do extra work so she gets more practice where she is having trouble." Interviewee $(10, \mathrm{SB})$. To this interviewee this is the best way for her to take the responsibilities of her daughter.

Finally, the observation of the researcher and schools policy document confirmed the above stated information on parenting and parental responsibilities towards their children. The researcher conducted home and school observation, in the process of this observation he observed the implementation of this parental involvement activity at homes and check their occurrences in the school policy documents. The home observation showed that parents of the two selected schools' children establish good home environments by providing the physiological needs that support their children in their schooling process. School documents also indicated that majority of the parents take care of the primary needs of their children only in very few cases that schools received complain from students on their primary needs.

\section{Communicating}


Communication is a process of designing effective forms of school to-home and home-to-school linkages concerning school programs and the progress of students. It is one of the parental involvement activities.

\section{Importance of Communication in the Schooling Process}

Communication is rated as the most effective means of ensuring student academic success. Parents need to be informed on their child progress, as well as all the activities and issues that involve the school at any time. The participants interviewed in this study expressed that communication was a necessary component in the educational process of their children and they explain that: "I always feel welcome to call the teachers if I have any questions or concerns. They are always willing to go out of their way to help my children and our family." Interviewee 04(SA).

One participant commented on his avenues for successful communication with the school. By talking to the teachers, writing notes and receiving announcements. He expressed,

"Communication at school takes place through talking with teachers, I write notes, and being a substitute teacher, sometimes, and hearing announcements. Also, I go to the PTO meetings sometimes when I can get back up to school."

Interviewee 15

(SA

Parent).

A participant's eagerness to communicate with his child's teacher is evident. Hence much of the importance is attached to it by this participant, being the only means for him to get involved in the school. He stated:

"I try to talk to Mrs. A at least once a week. I am usually at school and if I am not there, then I just send a note with my children. A lot of times I just need to ask about what fundraising activities we are going to work on next and start to try and come up with ideas for that".

Interviewee $14(\mathrm{SA}$

Parent).

When asked about the communication from the school to home, participant 08 (SB) responded by saying the teacher of his child has contacted him on several occasions, usually just in the hallway or even sometimes, 'she will send a note home asking about fundraising or could I sub for her.'

One participant is persistent in his efforts to communicate effectively with the school. He said: "I believe communication with the school about my children's educational progress is great. I know if my children are having trouble, I would be contacted and if I thought there was a problem that I could contact the school or teacher and a meeting or note would be sent and everything would be taken care of." 
Parent).

\section{Ways of School, Family and Community Communication}

Communication strategies such as family-teacher conferences and school progress reports rated most effective in ensuring increased student academic success. Family and community stakeholders want to feel welcome in the school and free to talk not only to teachers, but to the head teachers as well. Communication is a major vehicle of involving family and community into the schooling process of children. It was one of the themes most passionately embraced by all the participants of this study. This is one of the themes that all the participants had in common. Different modes of communication were presented throughout all interviews, even when the question which was not directly related to communication asked. In all the schools progress reports and parent conferences had been employed. These two methods of communicating are strongly encouraged by the school system as ways of informing parents of student progress with regard to their academic success in the school.

The participants in this study conveyed their views of school communications in a variety of ways. The communication forms included oral or written as deemed convenient by each participant. The interviewees presented their ways of communicating with school as" Writing notes" and "an occasional phone call to the teacher" 03(SA) was adequate for their children. "Some parents might want to talk to the teacher more, but I try not to take up much of the teacher's time. I know she/he is busy and will call me if something is wrong." It would be nice if the parents could get a list of times to call or an e-mail address to ask the teachers questions. "I think I would use e-mail more to communicate with the teacher if I had her/ his e-mail address or knew a good time to call her/him."

"As for communication between home and school, I always attend parent-teacher conferences .Also, one of my children's teachers did a monthly newsletter that was always sent home. I loved the newsletter because it let me know what was going on in the classroom and what to expect that was coming up. It helped me plan my work schedule better."

Interviewee

07(SA

Parent).

"I talk to the teacher about once every six weeks or so. I either call or go in to the conferences. I usually have questions about the homework the children say there is no homework, and then their performance come down, I have to either call or go by myself. “

$$
\text { Interviewee } 11
$$

Parent).

Participant 06 (SB) express his idea of communication as "most communication takes place through notes from the school office and the classroom teacher." He claims that his work schedule prevents him from going to most parent-teacher conferences, so his contact with the 
teachers has been either after school or before school starts or when he drop off or pick up the children. There has not been a need to contact his children's teachers. He receives the report cards and a lot of notes about what are going on at school. He feels sure that if he needs to know something about his children, that someone would call him from the school.

The researcher's observation in the two schools indicated that the schools use different means of communication to informed parents on the progress of their children as well as all the activities and issues that are related to schools. The observation revel to the researcher that in all the schools progress reports and parents conferences had been employed as a means of informing parents of students progress regarding their academic activities in the school. The documents of the schools indicated that (SA) employ the use of parents-teacher conferences, school progress reports, SMS, phone call, e-mail messages and PTA/PTO meetings as their means of communication. While in the case of (SB) the school documents indicated that the school employs the use of parent-teacher conferences, progress reports, SMS, sending mails as their means of communication. Both the researchers' observation and document of the schools established a solid ground on the importance and ways of home to school and school to home communication as a means of involving parent into the schooling process of their children.

\section{Volunteering}

Volunteering is a process of recruiting and organizing parental help and support at school. It is one of the parental involvement activities. The participants in this research described their experiences as volunteers at their children's schools. Whereby family members were purposefully involved in their child's schooling process. The schools represented in this study had both community and family volunteers. The schools were very proud of the family and community partnerships that they had nurtured.

\section{Ways of Volunteering to Schools}

Both family and Community partners shared financial and material resources as well as their time to volunteer to the schools of their children. Those who had the means to do so gave financially to support the school programs and head teachers' vision for incentives for teachers and students, and special projects. They gave materials such as school supplies and books. However, the most valuable gift from any one person or organization is time. The time that it takes to read to a child, to explain a math problem, to serve as mentor, and to provide training to teachers and parents cannot be measured in money. The following extracts, from the interviews reflect the ways of volunteering.

A parent described her volunteering experiences to the school of her child by stating that she help with holiday class when she was asked by the school and also she participated in all the events. Interviewee 03 (SA). 
Another participant view of volunteering activities included more than time. She participated in the school PTA/PTO meetings, made supply and rendered all type of assistance she can. She stated:

"I volunteered to send supplies for the PTO/PTA dinner and I work concessions for the school games when I can. I let the people in charge know when I am available and that I am willing to help and then they can let me know if they need my help."

Interviewee

05(SA

Parent).

However, in the case of (SB) they have few volunteering cases just very recently the school encourages PTA/PTO members to sacrifice their time at least once in a week to come and volunteer in the school so that the remaining parents should learn from their example. A volunteering PTA member and a parent have this to say;

"Before this time I had no idea that assistance was needed at school, I didn't know that teachers need to be help in their daily classroom activities through volunteer services from parents and community members. Now that I know i would definitely be more willing to help out more if I had enough notice to and I also wish that parent and community members should understand the importance of this volunteering and be willing to assist." Interviewee05 (SB parent).

Another interviewee from (SB) stated regretfully about her volunteering initiations:

"I didn't necessarily initiate the volunteering, but I also was not totally aware of what was going on. I don't mind assisting in events or helping with school activities, but I am not usually aware of everything that is going on or know what to do. If papers are sent home when he is not at our house, then I have no way to know anything that is going on at school. Many, many times in the past I had no idea that help was needed at school, and I hate this so much because we want to be involved. I would definitely be more willing to help out more if I had enough notice to ask off work or if the activities were scheduled at a different time than my work."

Interviewee 09

$(\mathrm{SB} /$

Parent).

The observation of the researcher in the two selected schools of the study indicated that both family and Community members shared financial and material resources as well as their time to volunteer to the schools of their children. The observation in (SA) shows that some family and community members gave financial supports to the school; others gave materials such as school supplies and books. While the remaining volunteer their time and energy through volunteering in the classrooms, teacher training and library. While in the case of (SB) the 
observation revel that the school has very few volunteers among family and community members. It is only recently that PTA/PTO members started volunteering in the school so that the rest family and community members should copy their style. The documents of the two schools established that (SA) has more volunteering activities from both the families and community members. While (SB) has no history of volunteering activities it now that the school is making effort to get both the family and community members involve in volunteering activities

\section{Learning at Home}

Learning at home is providing information and suggestions to families about how to help their children at home with homework and other curriculum related activities, decisions, and planning. It is one of the parental involvement activities being use by the parent to get involved in the schooling process of their children.

\section{Parental Facilitation of Learning at Home}

The participants of this study added their insightful information on their experiences and interactions with school staff involving learning at home. This insightful information as stated by the interviewees is present in the following:

One participant interviewed about learning at home explained her ideas as follows:

"We make it to be a clearly known policy in our house that school is number one over every other activity. We make activities for learning at home fun and try to find things that are hands-on for the children to do that helps them with their schoolwork. We always enter the science fair, whether their teacher requires it or not. My children do not always like to do the work at home, but I help them with that a lot and they love to do the experiments. I wish more children got involved with the science fair. My children, just love to take first or second position in the school and I give them all the encouragement they needed."

Interviewee 01

(SA

Parent).

Another participant interviewed responded to the learning-at-home inquiry in the following manner:

"If my children make the honor roll, my husband takes them somewhere to enjoy. My husband helps them with their homework when he takes care of them. I try to tell them to do their best because I do not want them to end up like me, working for minimum wage at two jobs just to take care of my family."

Interviewee 03

(SA

Parent). 
These interviewees explain the ways they participate in their children learning at home, such as assisting them with home work, given an extra teaching to them, creating special time for reading, given their children sufficient time to sleep and notorious food and finally encouraging their children by showing their love and concern to them.

A participant from (SB) felt very strongly about the idea of learning at home and had this to share about his rich experiences:

"Our children are encouraged to do well at home, school, Mosques or wherever else they in life might be. We use praise, special extras, and family night for giving them encouragement. We want them to feel like that doing things at home is just as important as being out in public or school and learning. We tell them that they can learn things everywhere." Interviewee 05 (SB Parent).

One more participant was asked by the researcher if there was anything that the school could do to make learning at home easier; this participant added the following to part of his learning at home encouragement,

"I do not have any problems being involved with my children's education. It is the most important steps in their life. It's not the school's problem to be accommodating to the home. I believe it is the parent's job to make sure their children, no matter what, gets an education and there are no excuses. I may be in my own world, but it is my job to raise my children to do their best and get the best education that I can give them in their life."

Interviewee

07(SB

/Parent).

The researcher's observation on parental help at home with their children home work and other school related activities reveled that majority of the family homes visited by the researcher contributed in one way or another towards their children education at home. Some families provide extra-classes at home while others participate actively in the studies of their children. From this observation only few parents indicated that they are busy, therefore they have no time for their children learning at homes and these parents believed that schools are doing enough to help their children with ideas of home work. And some families were proudly stating that this method is helping their children to make excellent results and because of this they praise and some time administer material rewards to them.

\section{Decision-Making}

Decision-making is a process of including parents in school decisions and developing parent leaders and representatives. It is one of the parental involvement activities that facilitate parental involvement in the schooling process of their children. 


\section{School Policy and Family Roles in Decision Making}

The participants of this research shared their experiences and decision-making opportunities at their children's school. An interviewee described her decision-making experience with her child's school. The school has an open-door policy for talking to the teachers and head teachers. She explained that she has attended Community meetings and helped come up with ideas on how to raise money for the school. 04 (SA).

Other participants stated the following about their experiences with decision-making in the schools of their children:

"I am aware that I have the right to make some decisions at the school. I have been involved in the PTA/PTO and while everyone was encouraged to participate, when it came right down to the decision-making, I felt that it was definitely not my decisions that were carried through. It seems like there were other, maybe stronger, opinions that were pushed and other ideas that were thrown out, and were never even considered to my knowledge."

Interviewee 12 (SA

Parent).

Another participant shared his decision making experience by stating that he go to every PTO meeting that he was invited and he was very involved with their activities. "I also sat in on a committee meeting to choose a layout for the new school sight."

Interviewee 10

(SA

Parent).

Even though some participants were minimally concerned while speaking of their decision-making involvement, yet the above interviewees presented their encouraging experiences with their children schools. It is clear that some parents' complaint can do a lot to change things in school, but, for the most part, the decisions made at the school and at the head office are for the benefit of general children.

Interviewee 06

(SA

Teacher).

Another interviewee spoke about his involvement in decision-making at the school and at the local education level:

"I talk to the school board member on a regular basis. He's our neighbor. He keeps me informed on the important things I need to know about at the school and even in the county at large. I trust him completely and I go straight to him and give him my opinions. I think it's better to just save your time and go straight to the top" 
Parent).

When he was questioned further about voicing his concerns to the school PTA/PTO members, interviewee 06 (SB) explained that he can't think of anything right off hand that the head teacher done just for him, "but his wife does call and let my wife know if the children are going to be two hours late or school has been cancelled and I appreciate that effort."

The researcher's observation on decision making in the two selected schools of the study revealed that the two schools involve parents in their decisions. The researcher's observation in (SA) showed that the school has an open-door policy when it comes to making decisions. They will try to have the opinions of parents before embarking into any activity of the school. On the parental side the observation results indicated that parents of (SA) are being involve in the decision making process of the school. Their opinion is invited and even encourage at school committee meetings. When they complain, their complain go a long way in changing things at the school.

In the case of (SB) the data of researcher's observation showed that; Teachers were not comfortable in involving parents into the school decision. Because according them, the attitude of parents is showing negligence on the school affairs therefore even when they are involve they may only waste the school time without providing any meaningful idea.

On the area of school documents the document of (SA) indicated that parents are fully involve in the decision making process of the school. While that of (SB0 indicated that the school is creating awareness to parents so that they should know the importance of their participation in the school decisions and participate.

\section{Collaborating With the Community}

Collaborating with the community is a process of identifying and integrating resources and services from the community to strengthen school programs, family practices, and pupils learning and development.

\section{Preparing the way for Community services}

A participant stated that he had not received any "help or support from the school or from any community services." he stated that he did, "volunteer from time to time at the some of the activities, but it was too depressing to volunteer on a regular basis. I would rather volunteer somewhere more upbeat."

$$
\text { Interviewee } 03
$$

Parent).

An interviewee 10 (SA Parent) talks about collaborating with community in the school of his child by explaining the fact that he did not know the school could help find additional services." He proceeded to say: I would love to get some extra tutoring for my children if it is 
free. I can't afford to pay, but any little bit of help would help us out so much. Also, it would have to be at school or somewhere that the bus could drop them off because of my work schedule."

An interviewee among the school teachers was questioned about the advantages of the many community services offered in his school. He quickly and frankly responded by saying "no, we don't need anybody's help. We'll be just fine. My pupils may not always have the best clothes or the finest shoes, but there will always be teachers going from one class to another. I appreciate the thought, but no thanks." Interviewee 08 (SB).

In the area of schools community services the interviewees denounce the knowledge of having such community services in the schools of their children. And the little that agree with existence of this community services express the need that their children should benefit with them. A parent participant stated that he had never taken advantage of community services, but that he:

"Would like to know more about what is offered." he further explained that he would like to, "get emails or notes to tell me about free tutors. My children could use any free tutoring services they could get."

Interviewee $\quad 09$

(SB

/Parent).

A classroom teacher participant stated her thoughts on community provided services and school aid where she indicated that they do not need any help. Almighty Allah has blessed them. Interviewee 05 (SB).

Therefore these responses indicated that some parents benefited with community collaboration services of their children schools. While in the other schools where there are no such services both the parents and teachers complain.

\section{Connecting the School with Families and Communities}

The following table provides a snapshot of what the interviewees shared in response to the Parental involvement activities of the two selected schools. By collecting the data and organizing it in the proper way the researcher was able to better analyze the regularity of the responses and connect them to the observation and the schools documentation evidence.

The table outlines the parental involvement activities that were employed by the schools to make connections with parents and community and the frequency with which they were discussed during the interviews sessions. In addition, because the respondents spoke specifically to the importance of each parental involvement activity, the information provided became useful in helping the researcher craft a narrative that descriptively tells the history of the selected sites for the study. After conducting and reviewing the interviews, it became obvious that some obstacles and suggestions for future success needed to be discussed fully to better understand the parental involvement experiences of the two schools. During the 
interview sessions each participant was asked to explain his experiences on the implementation of the six parental involvement activities so as to help the school in facilitating student academic success. In addition they should also identify some of the steps taken by the school to cultivate school, family, and community partnership.

\section{Table 4.4}

Data Collection Matrix: Base on Parental involvement activities

\begin{tabular}{lllll}
\hline $\begin{array}{l}\text { Involvement } \\
\text { activities }\end{array}$ & Interviews & $\begin{array}{l}\text { Number of } \\
\text { Responses }\end{array}$ & Observations & $\begin{array}{l}\text { School } \\
\text { policy }\end{array}$ \\
Parenting & Yes & $19 / 32$ & Yes & Yes \\
Communicating & Yes & $11 / 32$ & Yes & Yes \\
Volunteering & Yes & $07 / 32$ & Yes & Yes \\
Learning at home & Yes & $17 / 32$ & Yes & Yes \\
Decision Making & Yes & $15 / 32$ & Yes & Yes \\
Collaborating & Yes & $05 / 32$ & Yes & Yes \\
with Community & & & & \\
\hline
\end{tabular}

The researcher's observation on school community collaborations of the two selected schools indicated that (SA) collaborate with community to identify and integrate resources and services from the community to strengthen the programs of the school. While in the case of the (SB) the atmosphere in the school denounce having such services in the school. And even some of the school teachers indicated their disagreement with community services in their school.

The school documents of (SA) indicated that the school is engaged with community services, while that of (SB) indicated that the school is making effort to employ the services of community in order to facilitate teaching learning process in the school.

Lastly, the above discursions provide the scenario on how parent involve through the involvement activities. The discursion indicated that parents use the involvement activities to provide success in the schooling process of their children. They involve through the activities and influence the schooling process, this influence to the schooling process affect children academic success. This discursion which is base on the interviewees' responses, researcher's observation and school documents in each of the two selected sites of the study supported the 
research question reported earlier in this study asking how parent involve in the schooling process of their children through six typologies of parental involvement.

\section{Findings}

The finding of the study explores parent involvement through involvement activities. The coded frequencies of the study indicated that the results of the 25 out of the 32 interviews conducted in the two selected schools for this study have agreed with the researcher's observation and schools records in which the three set of results indicated that about (90\%) of parents involve in the schooling process of their children through parental involvement activities. And the result further indicated that those parental involvement activities are necessity for successful schooling process of the children. The breakdown of the result in line with involvement activities is as follows:

$>$ Parenting: The overall result of (SA) indicated that about $63 \%$ of the parents take care of their parental responsibilities in respect to their children schooling process. While in the case of (SB) the results indicated that $37 \%$ of the parents pay much attention to their parental responsibilities.

> Communication: The overall results of (SA) indicated that about $81 \%$ of the respondents are involved in home-school and school-home communication. However, in (SB) the results indicated that about $19 \%$ of the respondents are involved in communication with their children schools.

$>$ Volunteering: The results of (SA) in the area of volunteering indicated that about $85 \%$ of the respondents are engaged in some types of volunteer work at their children school. While in (SB) only about $14 \%$ of the respondents are involved.

$>$ Learning at home: The result in (SA) indicated that about $71 \%$ of the total respondents in the school attempted to nurture learning at home and wish for the best educational out come for their children. While in the case of (SB) the results indicated the commitment of about $29 \%$ of the respondents towards helping their children with home work and assignments on daily basis.

$>$ Decision making: The overall results of (SA) revealed that about $60 \%$ of the respondents experienced some level of decision-making input, either on the school building activities or the teaching /learning activities of the school. While in SB about $40 \%$ of the respondents indicated having similar decision making experience with their children schools.

$>$ Collaborating with community: The results revealed that that about $(66 \%)$ of the total respondents in SA took advantage of community services for the improvements of their children education. While the results of SB indicated that only about $33 \%$ of the respondents claimed to have benefited with community services in their children school. 


\section{Discussion}

The research question was formulated to explore parent involve in the schooling process through parental involvement activities. The coded frequencies of the study indicated that the results of the 25 out of the 32 interviews conducted in the two selected schools for this study have agreed with the researcher's observation and schools records in which the three set of results indicated that about (90\%) of parents involve in the schooling process of their children through parental involvement activities. And those parental involvement activities are necessity for successful schooling process of the children.

In the area of parenting about $63 \%$ of the total respondents of SA indicated that they discharge their parental responsibilities effectively and efficiently while in the case of SB about $37 \%$ of the responses fall under this category. This result agrees with researcher's observation in which almost the same figures were realised.

From the above discussion, it can be understood that absence of parental care at home leads to lack of parental involvement in the schooling process of their children as stated by Allen (2010). Furthermore parents are viewed as providers of security and they should therefore always protect their children by staying with them at home, and also make sure that they are also well-dressed in school uniform when they go to school. This could contribute to the comfortable, happy child, thus enhancing their academic success. The study indicated that Parents should therefore not leave their children alone at home. Furthermore they should make sure that their children do not go to school being hungry. They should provide them with food as a basic need before going to school; this statement is strengthened by the Gauteng Department of Education (2002). Because when parents neglected their parenting responsibilities it courses serious matters as learners could lose concentration and it may become difficult for them to learn, thus yielding poor academic success. In most cases learners who do not get a balanced diet, under-perform academically. This is supported by Bishop (1989) when stating that nutrient deficiency produces damage to the central nervous system and this will adversely affect the child holistically. On this note the present study therefore believed that parents who do not provide a stable and stimulating home background lay the foundation for an unhealthy, chaotic learning environment in schools.

In the area of school-parents communication 19 out of the 32 participants interviewed in this study reveled that they had at least one type of communication, oral or written, with their Children's school or teachers. The study showed that 18 out of the 32 participants had visited their children's school at least once or had an oral conversation with their children's teachers. And one parent sends a representative making the number to be 19 out of 32 . There for the study found that these participants had communicated through written correspondence such as notes or text messages and communicated through telephone. 
These findings are in agreement with prior research, which stated that clear two-way channels for communication must be established from home-to-school and school-to home. This dialogue keeps the home-to-school and school-to-home lines of communication open and flowing (Epstein, 2006). The study identified common communication barriers and the Participants of the study have commented on additional communication resources such as weekly progress reports, opening a school web page with classroom links, and varying hours for parent-teacher communications due to their work schedules, time constraints, and other family commitments.

In the close mark Examination of the 32 interviews conducted for the study it revealed that 17 out of the 32 participants engage in some types of volunteer work at their children's school. The Volunteer work ranged from "sending in supplies for the PTO/PTA meetings" and acting as "classroom teacher" to "volunteering in the library and reading room when it is needed." One of the participant stated, "The types of things that I enjoy doing most are helping in the library or helping teachers with activities in their classrooms."

However, multiple barriers for volunteer opportunities arose from this research work. The most prevalent volunteering barrier was found to be time factor. One participant made a remark that, "I don't have time to volunteer because I work all the time. I wish I had more time to help, but I just don't have time. Another participant also explained, "It would be more possible for me to volunteer at school if they would take care for my family's daily bread, so that I don't have to work."

The findings of the research surrounding volunteer work as a linked to parental involvement Agrees with the findings of this study. Epstein (2006) states that increased workloads, demanding schedules, and overall busy lives have greatly cut down on parents' volunteer activities. If educators expect more children to be successful in their schooling process, they must strive to form lasting partnerships with parents (Fried, 2001).

In the area of learning at home the study found that 29 out of the 32 participants attempted to nurture learning at home and wish for the best educational outcomes for their children. In their words some of the Participants stated such attempts as, "reading to my children at very young age," and encourage outside reading and activities." 22 out of the 32 participants stated that they helped their children with homework on one occasion or another and 20 out of the 32 participants' stated that they checked over homework assignments on a daily basis.

The study therefore, found consistencies with prior research surrounding learning at home. Many pupils and their parents will respond positively when steps are taken to personalize the Schooling process. Often pupils gain insight on skills, abilities, and test scores from the added concern at their respective homes. Many home work assignments are completed correctly and a positive attitude toward school work is put in place. Finally pupils usually become more self confident in their learning abilities and many times improve familial relationships through positive teaching at home (Epstein, 2006). 
The interviews conducted for this study also revealed that 17 of the 32 participants experienced some level of decision-making input, either on the school building activities or the teaching /learning activities of the school. 5 of the 32 participants did not have any input on decisions made neither on the building or the school activities. The reasons for not participating in the decision making process as stated by some parents included "not really interested in becoming more vocal in the decision making process," "I have never been asked to be involved in a decision making issue," and "I feel that most decisions made on the building and school activities are the benefit for the children." The reasons suggested for lower involvement ranged from lack of time and information to feelings or powerlessness and a low sense of individual and collective efficacy. The findings in this study are consistent with prior research findings and provide further suggestions for lack of parental involvement in the decision making process of the school.

Also 17of the 32 participants of this study took advantage of community services for the improvements of their children education. In collaborating with the community, parents or caretakers are provided with links to multiple community resources and services through the school. Participants reported that they took advantage of dental services such as fluoride and teeth sealants, and healthcare related services such medical clinics for families with no health insurance facilities. One participant's has taken advantage of an Islamic-based program that was offered at school. Some participants voiced out there need for free tutoring services for their children. None of the 32 participants revealed whether their children took advantage of the other community assisted programs in their schools.

These findings of the study are consistent with findings from prior studies. In which Communities provide opportunities for children to learn how to act in the world around them, to explore, express, earn, belong, and influence through such venues as school-sponsored programs, religious and volunteer organizations (Newman et al., 1999).

\section{Recommendations for the Study}

The six components of Joyce Epstein's typologies of Parent Involvement were largely supported by this study. School-family and community members, and all involved stakeholders must provide the necessary information to make links between home-school and community more prevalent. In this regards the present research study suggests that these links are pivotal for a successful schooling process of our children. As a result, the following recommendations are suggested.

Schools within Katsina should:

1. Enlighten parents that their involvement in the schooling process of their children is directly related to their academic success. 
2. Communicate to parents the significance of parental involvement and create ways to enhance parental involvement practices in their schools which will bring about the formation of schools, families, and communities partnership.

3. Increase communication opportunities between school and home through introducing various opportunities and modalities that are imperative for involving all parents and caregivers in the schooling process of their children.

4. Plan and communicate in a timely manner multiple opportunities for volunteering activities. This includes various opportunities, times, dates and locations that must be considered in order to accommodate all the interested parties in the partnership.

5. Build on existing practices of learning at home. By providing information on the successful assistance practices including homework assistance, school related activities, and methods of encouraging our pupils to do their home work.

6. Provide relevant information surrounding decision making activities and solicit parent Involvement in all decisions of the school.

7. Provide informational materials that relate community services and their resources to parents and all other members of the community.

8. Investigate specific barriers to school, family and community partnerships and execute programs to help in reducing these barriers.

\section{Conclusion}

Advocates of parental involvement in the schooling process encourage schools to maintain a strong relationship with families and their communities (Sleeter \& Grant, 2007). This should include cooperation towards implementing the six typologies of parental involvement and providing conducive atmosphere for understanding between teachers, parents and the institution for an effective comprehensive parental involvement programme. This is important as the family is the most immediate and perhaps the most influential system affecting the child (Walsh \& Williams, 1997). However, ultimately the success of all parental involvement programmes within school communities will depend on how well the programme matches up with the needs of all parents and caregivers. This means that if a school is sincere in providing education that will lead to the success of all learners, it would do well to involve all parents in this endeavour.

\section{Acknowledgements}

I would like to extend my gratitude and appreciation to all the individuals who volunteered to participate in this study. A special thanks to the two head teachers of the two Primary schools in Katsina who welcomed me and provided access to participants and materials.

Finaly i cannot conclude this acknowledgement without extending my profound gratitude and appreciation to the individuals who provided help during this study. 


\section{References}

Abdullahi, S. U. (1996). Parent teacher association (PTA) as an instrument of community participation in Education. Congo conference hotel Zaria. Journal of Educational Policy 23.

Adeyemo, D. (2005). Parental involvement, interest in schooling and school environment as Predictors of academic self-efficacy among fresh secondary school students in Oyo State, Nigeria. Electronic Journal of Research in Educational Psychology, 3(1), 163-180.

Adenike, A., \& Oyesoji, A. (2010). The relationship among predictors of child, family, school, society and the government and academic achievement of senior secondary school students in Ibadan, Nigeria. Procedia-Social and Behavioral Sciences, 5, 842-849.

Adepoju, T. (2010). Motivational variables and academic performance of urban and rural secondary school students in Oyo state, Nigeria. KEDI Journal of Educational Policy, 23.

Allen SM 2010. Parental Involvement, Family Structure and Academic Achievement. M. A. Sociology Thesis. California: Sacramento.

Banks, J. A., \& Banks, C. A. M. (1997). Multicultural education: Issues and Perspectives. Boston: Allyn and Bacon.

Bishop G 1989.Alternative Strategies for Education. Hong Kong: MacMillan.

Bastiani, J. (1996). Parent involvement. Paper presented at a seminar on Parent Involvement, 26 March 1996, Rand Afrikaans University.

Bogdan, R. C., \& Biklen, S. K. (1992). Qualitative Research for Education: An Introduction to Theory and Method. Boston: Allyn and Bacon.

Botha, R. J. (2000). Managing the school as an organization. Unisa Tutorial letter 104/2000 for MEDEM 5-R. Pretoria: University of South Africa. 
Chavkin, N. F. (1989). A multicultural perspective on parent achievement: implications for policy and practice. Education Spring, 109(3), 276-285.

Chavkin, N. F. (1993). Families and Schools in a Pluralistic Society. Albany: State University of New York.

Department of Education 2002. School Management Teams. Managing and Leading Schools. Pretoria: Government Printers.

Eisenhardt, M., \& Towen, L. (2003). Contestation and change in National Policy on "Scientifically based" educational research. Educational Research, 32(7), 31-38.

Epstein, M. (1998). School-family-community partnership inmiddle and higher schools from theory to practice. US: centre for research on education of students place at Risk (CRESPAR).

Epstein, \& Sanders, M. (2006). Connecting home, school, and community. Handbook of the sociology of education, 285-306.

Epstein. (1996). Advances in Family, Community, and School Partnerships. Community Education Journal, 23(3), 10-15.

Epstein, J. L. (1995a). School, family, community partnerships: caring for the children we share. Phi Delta Kappan, May, 701-712.

Epstein, J. L. (1995b). Perspectives and previews on research and policy for school, family and community partnerships. In A. Booth \& J. Dunn (Eds.), Family-school links: How do they effect educational outcomes? Hillside, NJ: Erlbaum.

Epstein, J. L. (2001). School, Family and Community Partnerships: Preparing educators and improving schools. USA: Westview Press.

Epstein, L., \& Dauber, S. L. (1993). Parents' attitudes and practices of involvement in inner-city elementary and middle schools. In N. Chavkin (Ed.), Families and Schools in a Pluralistic Society. Albany, NY: State University of New York.

Epstein, J. L., \& Sanders, M. G. (2000). Connecting home, school and community: New directions for social research. In M. Hallinan (Ed.), Handbook of the Sociology of Education. New York: Kluwer.

Gillham, Bill (2000). Case study research methods. London: Continuum

Hammersley,H. and Atkinson P. (1993) Ethnography: Principles in practice. London: Routledge.

Hatch, J. E. (2002). Doing qualitative research in education settings. Press. Albany: SUNY.

Henderson, A. T., \& Mapp, K. (2002). A New Wave of Evidence: The impact of school, family, and community connections on student achievement. Austin: Southwest Educational Laboratory.

Hester, H. (1989). Start at home to improve home school relations. NASSP Bulletin, January, $23-27$. 
Hurst, A. (2009). Parental involvement Typologies in rural community school A Qualitative investigation. . Doctor of philosophy, East Tennessee state University, East Tennessee.

Jones, L. T., \& Blendinger, J. (1994). New beginnings: Preparing future teachers to work with diverse families. Action in Teacher Education, 16(3), 79-86.

Kazeem, K., \& Musa, N. (2008). Partnership that Works: A Study of the Educational-Web in School Management. College Student Journal, 42(4), 11.

Lawal, R. A. (1985). An analysis of reading habits of Nigerian secondary school students: A case-study of form four students in Oyo. Unpublished M. Ed. Dissertation. Faculty of Education, University of Ibadan. Ibadan, Nigeria.

Lemmer, E. M. (2000). The Epstein Model of Family school partnership: teachers' experiences in South African schools. Educare, 29(1\&2), 60-75.

Lemmer, E. M. (2007). Parental involvement in teacher education in South Africa. 6th International conference of the European Research Network about Parents in Education (ERNAPE). Nicosia, Cyprus. August 29-31.

Lincoln, Y. S., \& Guba, E. G. (1985). Naturalistic inquiry. . Beverly Hills, CA: Sage.

Merriam, S.B. (1998). Qualitative research and case study applications in education. San Francisco: Jossey-Bass.

Maxwell, J. A. (Ed.). (2005). Qualitative research design: An interactive approach Thousand Oaks, CA: Sage.

McMillan, J.H. \& Schumacher, S. (2001). Research in Education: A Conceptual Introduction, 5thed. New York: Longman.

Morse, J. M. (1994). Designing funded qualitative research. : Thousand Oaks, CA: Sage.

National Policy on Education, R. E. (1981; 1994; 2004 editions). National Policy on Education,(Rev. Ed.), . Nigeria: Lagos: NERCPress Ltd.

Newman, T. (2002) Promoting Resilience in children and young people during periods of transition (2002), Scottish Executive, Edinburgh. Available athttp://www.scotland.gov.uk/library5/education/ic78-00.asp

Neumann, W. L. (1999). Social Research Methods: Qualitative and Quantitative approaches. Needham Heights: Allyn and Bacon.

NREL. (1999). . National Center for Photovoltaics, Golden, Colorado USA.

Okebukola, F. O. (2004) Children's emergent reading in English: From theory to practice. . Literacy and Reading in Nigeria,, 10((1)).

Patton, M. Q. (1990). Qualitative evaluation and research methods. Sage Newbury Park, CA.

Strauss, A.,, \& Corbin, J. (1990). Basics of qualitative research: Grounded theory procedures and Techniques. Newbury Park, CA: Sage.

Rousseau, D. M., \& Fried, Y. 2001. Location, location, location: Contextualizing organizational research. Journal of Organizational Behavior, 22: 1-13.

Spradley, J. P. (1979). The ethnographic interview. New York: Holt, Rinehart \& Winston 
Sleeter, C. E., \& Grant, C. A. (2007). Making Choices for Multicultural Education. New York: Wiley.

Van der Linde, N. (1997). Managing multicultural schools. Unisa manual for EDE MCI-E. Pretoria: University of South Africa.

Van Wyk, N., \& Lemmer, E. (2009). Organising parent involvement in South African Schools. Cape Town: Juta.

Walsh, M. W., \& Williams, G. R. (Eds.) (1997). Schools and Family Therapy. Springfield: Charles C Thomas.

Woody, A. (2010). Educational leaders as catalyst for connecting school and community: uncovering leadership strategies for forging school, family, and community partnerships.

Zimbabwe, H. (1992). Commonwealth committee of foreign ministers on Southern Africa: Sixth meeting, New Delhi, 13-14 September 1991. The Round Table, 81(321), 93-97. 